\title{
PERANAN SUMBERDAYA HUTAN DALAM PEREKONOMIAN DAN DAMPAK PEMUNGUTAN RENTE HUTAN TERHADAP KELESTARIAN HUTAN DI KABUPATEN GOWA
}

\author{
Role of Forest Resource in Economy and the Impact of Forest Rent to Forest Sustainability in \\ Gowa Regency
}

Syamsu Alam dan Hajawa

\begin{abstract}
Kabupaten Gowa has 63.099 ha forest area, consists of 24.226 ha of protected forest, 3.309 ha of conservation forest/recreation forest, and 35.554 ha of production forest. The value of forest resource can be estimated based on use value an non use value. Use value of forest resource in Kabupaten Goewa covers direct economic value wich is obtained from timber product and non timber product. While indirect economic value is obtained from iriigation water, fresh water, agriculture production increase, and forest recreation value and also contribution in labour section. Contribution of agricultural sector in Bruto Regional Domestic Product (Produk Domestik Regional Bruto = PDRB) of Kabupaten Gowa base on the data of 2000 to 2005 is high enough, more than half of PDRB of Kabupaten Gowa which is 52,29\%. However the contribution of subsector of forestry to the economy of Kabupaten Gowa is very small, only $0,17 \%$. the use of ecpnomy rent for land of rehabilitation in 2005 has been use as much as Rp. 142.384.858,- for 95,50 ha of area. This fund is come from Dana Alokasi Khusus - Dana Reboisasai(DAKDR)40 \% (special allocation fund-reforestration fund $40 \%$ ) the part is managed by the region of production.
\end{abstract}

Key words: Forest rent, forest sustainability

\section{PENDAHULUAN}

Hutan merupakan salah satu sumberdaya alam yang memiliki nilai ekonomi, ekologi dan sosial yang tinggi. Hutan alam tropika juga berfungsi sebagai paru-paru dunia dan sistem penyanggah kehidupan sehingga kelestariannya harus dijaga dan dipertahankan dengan pembangunan hutan yang tepat. Berdasarkan Undang-Undang Kehutanan Nomor 41 tahun 1999, pembagian hutan di Indonesia berdasarkan fungsinya adalah hutan konservasi, hutan lindung dan hutan produksi.

Indonesia memiliki luas hutan 120 juta ha, 58 juta ha adalah kawasan hutan produksi (48\%), 33,5 juta ha kawasan hutan lindung $(28 \%), 20,5$ juta ha kawasan hutan konservasi (17 \%) dan 8 juta ha kawasan hutan yang dapat dikonversi atau 7 \% (Paduserasi TGHK dan RTRWP, 1999 dalam Riyanto, 2004). Ini artinya, bahwa sejak awal telah diprioritaskan porsi terbesar adalah hutan produksi yang akan memproduksi hasil hutan (terutama kayu) dalam pembagian kawasan hutan Indonesia guna menopang ekonomi nasional yang buruk pada era 60 an. Sisanya dilindungi dan dikonservasi $(45 \%)$ dan sebagian kecil $(7 \%)$ diperuntukkan guna kepentingan di luar kehutanan. Pada dasarnya sejak awal telah dilakukan pembagian kawasan berdasarkan fungsinya yang cukup arif dan dituangkan dalam Tata Guna Hutan Kesepakatan, dengan harapan dapat dikelola sesuai fungsinya sehingga memberikan manfaat optimal untuk kepentingan negara dan masyarakat (Riyanto, 2004).

Berdasarkan data yang ada luas hutan produksi di Indonesia adalah 57,7 juta ha dan yang dikelola oleh pemegang ijin usaha pemanfaatan hasil hutan kayu seluas 37,58 juta ha serta sisanya seluas 20,12 juta ha tidak terdapat pengelolanya. Hal ini menunjukan bahwa hanya $65,13 \%$ dari luas hutan produksi yang dikelola sedangkan sisanya atau $34,87 \%$ dari luas hutan produksi tidak dikelola (Pusat Wilayah Pembentukan Kawasan Hutan, 2006). Pada kawasan yang tidak terdapat pengelolanya maka pemerintah dan pemerintah daerah harus mengambil peran dalam pembangunan hutan 
tersebut, hal ini telah diamanahkan pada UU No. 41 Tahun 1999 tentang Kehutanan.

Kabupaten Gowa adalah salah satu kabupaten yang terdapat di Sulawesi Selatan, memiliki luas wilayah $1.883,33$ kilometer persegi atau sama dengan 3,01 persen dari luas wilayah Propinsi Sulawesi Selatan. Sebagian besar wilayah Kabupaten Gowa adalah dataran tinggi yaitu sekitar 72,26 persen. Dari total luas kabuaten Gowa, 35,30 persen adalah daerah yang memiliki kemiringan lereng di atas 40 persen. Luas penggunaan lahan kering di Kabupaten Gowa mencapai 153.965 ha dan diantaranya terdapat 43,04 persen adalah hutan (Kabupaten Gowa dalam Angka, 2006).

Besarnya persentase luas kawasan hutan di lahan kering kabupaten Gowa dapat diperkirakan akan mempunyai peranan yang cukup besar baik dari aspek ekologi, sosial maupun ekonomi. Untuk mengetahui seberapa besar peranan sumber daya hutan ini terhadap perekonomian dan kelestarian hutan itu sendiri, maka perlu dikaji peranan ini pada berbagai sektor ekonomi.

\section{PERANAN SUMBERDAYA HUTAN DALAM PEREKONOMIAN DI KABUPATEN GOWA}

\section{Nilai Sumberdaya Hutan}

Hutan adalah suatu kesatuan ekosisitem berupa hamparan lahan berisi sumber daya alam hayati yang didominasi pepohonan dalam persekutuan alam lingkungannya, yang satu dengan lainnya tidak dapat dipisahkan (UndangUndang Kehutanan No. 41 tahun 1999). Lebih lanjut diuraikan bahwa hutan mempunyai tiga fungsi yaitu:

1. Fungsi konservasi yaitu hutan konservasi

2. Fungsi lindung yaitu hutan lindung

3. Fungsi produksi yaitu hutan produksi

Sumberdaya hutan memiliki kelainan (peculiaritas) atau kekhasan dalam penilaian ekonomi, seperti yang dikemukakan oleh Duerr, (1962); Leslie, (1964); Warrell, (1960) dalam Wirakusumah (2003) bahwa kelainan-kelainan atau sifat-sifat khas sumberdaya hutan yang dimaksud adalah sebagai berikut:

1. Produk sumberdaya hutan senantiasa dalam proses produksi yang berlainan dengan produksi dalam suatu pabrik yang meramu bahan mentah melalui suatu proses teknologi yang dapat diatur waktunya; proses produksi sumberdaya hutan tergantung alam memerlukan waktu lebih lama.

2. Kayu sebagai salah satu produk utama sumberdaya hutan yang penting diambil dari pohon-pohon beragam umur memerlukan jumlah persediaan yang cukup besar (luas dan volumenya) dengan sendirinya menuntut proses dan manajemen yang tidak sederhana

3. Akibat situasi di atas, massa kayu yang merupakan tegakan yang senantiasa tumbuh itu tidak mudah dibedakan apakah merupakan produski akhir atau sebagai modal yang sedang dalam pertumbuhan

4. Sumberdaya hutan memiliki potensi menghasilkan sekaligus banyak komoditi dan jasa serbaguna bersamaan (joint product).

5. Banyak komoditi/jasa serbaguna belum terukur nilainya secara tepat oleh hukum permintaan dan penawaran.

Peranan sumberdaya hutan dalam perekonomian dapat dilihat dan dilakukan melalui kegiatan pemanfaatan hutan. Sebagaimana yang tertuang dalam Undang-Undang Kehutanan Nomor 41 tahun 1999, bahwa pemanfaatan hutan bertujuan untuk memperoleh manfaat yang optimal bagi kesejahteraan seluruh masyarakat secara berkeadilan dengan tetap menjaga kelestariannya. Pemanfataan kawasan hutan dapat dilakukan pada semua kawasan hutan kecuali pada hutan cagar alam dan zone inti serta zone rimba pada taman nasional. Pemanfaatan hutan produksi dapat berupa pemangfaatan kawasan, pemanfaatan jasa lingkungan, pemanfaatan hasil hutan kayu dan bukan kayu serta pemungutan hasil hutan kayu dan bukan kayu.

Sementara itu manfaat yang dapat diberikan oleh hutan lindung terutama adalah peranannya dalam fungsi hidroorologi, sebagai perlindungan kawasan dibawahnya dari bahaya banjir dan erosi, walaupun disisi lain dapat dimanfaatkan hasil hutan non kayu yang dihasilkan oleh hutan lindung, dan jasa lingkungan.

Penilaian ekonomi terhadap sumber daya hutan didasarkan atas manfaat yang dapat disumbangkan, baik manfaat langsung maupun manfaat tidak langsung. Sebagaimana yang dikemukakan oleh Soeparmoko (2002) tentang nilai sumberdaya hutan. Bahwa sumberdaya hutan dapat dinilai berdasarkan: 
1. Nilai penggunaan (instrumental value $=u s e$ value), yang meliputi nilai penggunaan langsung (direct use value), misalnya nilai hasil hutan kayu dan nilai hasil hutan non kayu , dan nilai penggunaan tak langsung (indirect use value), serta nilai penggunaan pilihan (option use value)

2. Nilai tanpa penggunaan (intrinsic value $=$ non use value), yang meliputi nilai pewarisan (bequest value) dan nilai keberadaan (existance value).

Nilai ekonomi sumberdaya hutan di Kabupaten Gowa bukan hanya dapat dihitung berdasarkan nilai dari potensi kayu yang terdapat di dalam hutan produksi, tetapi berbagai aspek dapat dinilai dari sumber daya hutan tersebut

\section{Potensi Hutan Kabupaten Gowa}

Tidak semua komoditi sumberdaya hutan merupakan komoditi akhir (final commodity) karena tidak semua kayu gergajian adalah benda konsumsi (consumer good) yang langsung digunakan misalnya untuk pembangunan rumah. Tetapi beberapa di antara kayu gergajian diproses ke industri pengeringan/pengawetan yang kemudian dijual ke industri rekayasa (woodworking industry) seperti untuk kusen atau industri perkakas (meubel). Ragam produksi primer sumberdaya hutan meliputi kayu bulat, air, proteksi, hasil hutan non kayu seperti rotan, buahbuahan dari pohon hutan dan lain-lain (Wirakusumah, 2003).

Luas hutan di Kabupaten Gowa tahun 2004/2005 seluas 63.099 ha yang terdiri dari 24.226 ha hutan lindung, 3.309 ha hutan suaka alam/hutan wisata dan 35.554 ha hutan produksi yang terdiri dari hutan produksi tetap 22.105 ha dan hutan produksi terbatas 13.455 ha (Kabupaten Gowa dalam Angka, 2006).

Kondisi penutupan hutan Kabupaten Gowa, yang berhutan seluas $18.836 \mathrm{Ha}$, kawasan yang tidak berhutan seluas 34.028 ha, dan yang tertutup awan seluas 10.235 ha. Terlihat bahwa luas hutan yang masih tersisa sangat sedikit dibanding dengan kawasan hutan yang tak bervegetasi. Hal ini sangat rawan dalam menciptakan lahan kritis di Kabupaten Gowa.

Luas lahan kritis di dalam kawasan hutan seluas 35.499,62 Ha dan lahan kritis di luar kawasan hutan adalah $5.054,36 \mathrm{Ha}$.

\section{Nilai Ekonomi Langsung Hutan di Kabuapten Gowa}

\section{Produksi kayu}

Nilai ekonomi langsung dari hasil hutan kayu dapat diperoleh melalui hasil penjualan dari sejumlah kayu tersebut. Sementara nilai ekonomi langsung dari hasil hutan kayu yang menjadi sumber pedapatan daerah berasal dari hasil penarikan retribusi pengangkutan hasil hutan kayu dan pajak penjualan kayu tersebut.

Produksi kayu hutan untuk Kabupaten Gowa dapat diperinci sebagai berikut;

1. Tahun 2004, produksi kayu bulat sebesar $853,80 \mathrm{~m}^{3}$

2. Tahun 2005 , produksi kayu bulat sebesar $893,4 \mathrm{~m}^{3}$, yang terdiri dari kayu jati bulat sebanyak $124,00 \mathrm{~m}^{3}$ dan kayu campuran rimba sebanyak 769,4 $\mathrm{m}^{3}$. Terjadi peningkatan sebesar 4,64 persen. (Kabupaten Gowa dalam Angka, 2006).

Industri Izin Pemanfaatan hasil Hutan Kayu (IPHHK) di Kabupaten Gowa tahun 2005, sebanyak 3 buah (Dinas Kehutanan Propinsi Sulawesi Selatan, 2005) yaitu:

1. CV. Sulawesi Trans Mandiri, dengan produksi $39,88 \mathrm{~m}^{3}$.

2. PT. Tombongi Permata Raya, dengan produksi $1.121,20 \mathrm{~m}^{3}$.

3. PT. Panrita Mangkasara, dengan produksi $272,64 \mathrm{~m}^{3}$.

Total produksi sebanyak $1.433,72 \mathrm{~m}^{3}$. produksi kayu gergajian sebanyak $3.500 \mathrm{~m}^{3}$ (industri hulu)

\section{Produksi hasil hutan bukan kayu}

Produksi hasil hutan bukan kayu di Kabupaten Gowa tahun 2005 berasal dari penyadapan getah pinus. Penyadapan getah pinus sebanyak 37,45 ton (Dinas Kehutanan Propinsi Sulawesi Selatan, 2005).

Baik produksi kayu maupun produksi hasil hutan bukan kayu, tidak ditemukan nilai dalam bentuk rupiah atau nilai uang, sehingga sulit untuk memprediksi kontribusi sektor kehutanan berdasarkan produksi tersebut.

\section{Nilai Ekonomi Tidak Langsung Hutan di Kabuapten Gowa}

\section{Nilai air irigasi}

Data mengenai volume air irigasi di Kabupaten Gowa, tidak disajikan dalam statistik 
kabupaten. Namun dapat dipastikan bahwa irigasi di Kabupaten Gowa tidak terlepas dari adanya bendungan dan sub Das. Berbicara mengenai sub das, terdapat 10 sub Das di Kabupaten Gowa, yaitu :

Table 1. Sub watershed in Kabuapten Gowa

\begin{tabular}{|c|l|r|}
\hline No & Sub watershed name & \multicolumn{1}{c|}{ Luas (ha) } \\
\hline 1. & Kelara & $26.181,30$ \\
2. & Jeneberang hilir & $24.998,78$ \\
3. & Jenelata & $23.773,90$ \\
4. & Lengkese & $20.186,25$ \\
5. & Malino & 15.872 .40 \\
6. & Tallo & $22.805,12$ \\
7. & Pappa & $6.690,45$ \\
8. & Puncara & $2.871,48$ \\
9. & Taman roya & $10.830,88$ \\
10. & Tanggara & $14.368,40$ \\
\hline & Jumlah & $390.224,56$ \\
\hline
\end{tabular}

Sumber : Dinas Kehutanan Sulawesi Selatan, 2005

Luas total Das di Sulawesi Selatan adalah $6.146 .789,55$ ha. Persentase luas Sub Das di Kabupaten Gowa dibandingkan Sulawesi Selatan sebesar 6,35 \%. Sub Das yang terdapat di Kabupaten Gowa, merupakan bagian dari Sub Das yang terdapat di kabupaten lain yang berdekatan dengan Gowa seperti Sinjai, Takalar, Jeneponto, Maros dan Makassar. Sub Das ini mempunyai sumbangsi terhadap pengairan lahan sawah di Gowa.

\section{Nilai konsumsi air minum}

Peranan hutan dalam penyediaan konsumsi air bersih dapat dihitung berdasarkan volume air bersih yang dihasilkan oleh DAM Bili-Bili. Dimana Dam Bili-Bili mensuplai air bersih bagi Kabupaten Gowa dan sebagian wilayah Makassar.

Kontribusi air bersih terhadap Pendapatan Domestik Regional Bruto (PDRB) Kabuapten Gowa sebesar:

1. Tahun 2000 sebesar Rp. 315,74 juta

2. Tahun 2001 sebesar Rp 658,26 juta

3. Tahun 2002, sebesar Rp 1.132,89 juta

4. Tahun 2003, sebesar Rp. 1.345,03 juta

5. Tahun 2004, sebesar Rp. 1.943,21 juta

6. Tahun 2005, sebesar Rp. 2.170,48 juta

Persentase kontribusi air bersih terhadap

Produk Domestik Regiona Bruto (PDRB) Kabupaten Gowa khusus untuk tahun 2005 adalah sebesar 0,102 \%.

\section{Nilai peningkatan produksi pertanian}

Perhitungan nilai air untuk pertanian didasarkan pada:

1. Jumlah air yang dibutuhkan dalam periode satu tahun $\left(\mathrm{m}^{3} / \mathrm{th}\right)$ dikalikan harga air per satuan $\left(R p / m^{3}\right)$. Harga air per satuan merupakan kemauan masyarakat untuk membayar (willingness to pay). Jika dalam suatu wilayah sudah terdapat ketentuan untuk iuran jasa air, tentunya akan lebih mudah menghitungnya. Bila belum ada dapat dilakukan survey berapa masyarakat mau membayar seandainya pemanfaatan jasa air ditarik iuran. Itulah nilai hutan untuk tujuan peningkatan produksi pertanian.

2. Berdasarkan produksi sawah beririgasi, yaitu jumlah pendapatan dari hasil panen pada musim kemarau dikurangi dengan biaya produksi. Itulah nilai hutan untuk tujuan peningkatan produksi pertanian, dengan perhitungan sebagai berikut:

a. Jumlah pendapatan dari hasil panen pada musim kemarau yaitu jumlah panen padi / gabah kering atau beras dalam ton perhektar dikalikan dengan harga gabah atau beras. Nilai ini dikalikan dengan luas sawah beririgasi di suatu wilayah.

b. Biaya produksi yaitu biaya tetap dan biaya variabel yang dikeluarkan dalam kegiatan pertanaman padi dalam satu musim tanam, misalnya musim kemarau dimana sawah membutuhkan air irigasi.

Peranan ini dapat disumbangkan melalui peranan hutan dalam menjaga tata air, sehingga setiap saat persediaan air untuk kegiatan irigasi dapat terpenuhi.

Luas lahan sawah beririgasi di Kabupaten Gowa adalah :

1. Sawah beririgasi teknis seluas 9.791 ha

2. Sawah beririgasi Semi Teknis seluas $4.567 \mathrm{Ha}$

3. Jenis pengairan sederhana seluas $2.286 \mathrm{Ha}$.

Luas panen padi sawah adalah 46.388 ha dengan produksi sebesar 231.858 ton. Produksi ini dapat dikatakan sebahagian berasal dari sawah beririgasi. Dimana luas sawah irigasi sebesar $16.644 \mathrm{Ha}$ (Kabupaten Gowa dalam Angka, 2006).

Berdasarkan hasil percobaan Balai Besar Penelitian Padi Sukamandi, padi hibrida menghasilkan gabah kering sebanyak 6-9 ton perhektar. Bila mengambil nilai rata-rata, maka 
dapat dikatakan bahwa produksi gabang kering rata-rata 7,5 ton per ha permusim panen.

Berdasarkan data di atas dapat ditaksir bahwa jumlah panen gabah kering yang berasal dari sawah irigasi pada musim kemarau di Kabupaten Gowa sebesar $16.644 \mathrm{Ha}$ X 7,5 ton per ha sama dengan 124.840 ton. Bila ditaksir bahwa dalam 1 ton padi gabah kering setara dengan 0,4 ton beras. Maka jumlah beras yang dihasilkan adalah 49,936 ton. Harga perkilogram beras dipasaran sekitar Rp. 5.500,-. Harga beras keseluruhan dari produksi sawah beririgasi dalam musim kemarau sebesar Rp. 274.648.000,- (dua ratus tujuh puluh empat juta enam ratus empat puluh delapan ribu rupiah).

Untuk biaya produksi, dapat dihitung dengan menghitung:

1. Biaya tetap, meliputi pajak bumi dan bangunan, biaya penyusutan dari harga peralatan cangkul, dan sewa lahan

2. Biaya variabel, meliputi biaya bibit, pupuk, pestisida, sewa traktor, dan tenaga kerja

\section{Nilai rekreasi hutan}

Kuantifikasi nilai nominal berdasarkan kesediaan membayar diterapkan juga untuk menghitung manfaat wisata kawasan hutan. Kemauan masyarakat untuk membayar (willingness to pay) untuk dapat berekreasi $\mathrm{di}$ kawasan hutan wisata. Selain itu Metode Travel cost dapat pula dipergunakan untuk menilai manfaat suatu kawasan hutan yang dimanfaatkan untuk berwisata.

Metode travel cost dihitung dengan cara berapa jumlah biaya yang harus dikeluarkan oleh wisatawan untuk dapat berekreasi di hutan wisata, misalnya seorang wisatawan yang akan berkunjung ke Taman Wisata Alam Malino, ia harus mengeluarkan biaya untuk transportasi, makanan, minuman, penginapan dan sebagainya.

Hutan menyajikan suatu pemandangan yang indah, dapat menjadi objek wisata, seperti misalnya Taman Wisata Alam Malino. Nilai rekreasi hutan dapat diberikan melalui pembayaran retribusi. Retribusi ini meliputi; retribusi ke tempat wisata, retribusi jasa angkutan wisata, retribusi jasa penginapan, retribusi jasa rumah makan dan lain-lain.

Nilai rekreasi hutan merupakan akumulasi dari nilai retribusi, dan nilai atau dana yang dikeluarkan oleh seorang wisatawan untuk dapat menikmati rekreasi hutan tersebut.

\section{Sumbangan dalam ketenagakerjaan}

Penyerapan tenaga kerja dari sektor kehutanan sulit untuk dijelaskan. Dalam data statistik pengelompokan ketenagakerjaan terlalu makro, misalnya dengan kategori pegawai, pekerja bebas pertanian, dan pekerja bebas non pertanian.

Yang dimaksudkan pekerja bebas pertanian adalah seseorang yang bekerja pada orang lain/majikan/institusi yang tidak tetap (lebih dari satu majikan dalam sebulan terakhir) diusaha pertanian, baik berupa usaha rumah tangga maupun bukan usaha rumah tangga atas dasar balas jasa dengan menerima upah atau imbalan baik berupa uang maupun barang dan baik dengan sistem pembayaran harian maupun borongan. Usaha pertanian meliputi pertanian tanaman pangan, perkebunan, kehutanan, peternakan, perikanan dan perburuan, termasuk juga jasa pertanian (Keadaan pekerja di Indonesia , BPS 2006).

Kategori yang tersebut di atas menunjukkan kesulitan dalam melihat kontribusi kehutanan dalam sektor ketenagakerjaan. Dalam data statistik, ketenagakerjaan sub sektor kehutanan masih bergabung dengan sub sektor lain dalam lingkup pertanian. Di samping itu tenaga kerja di Kabupaten Gowa, sangat jarang yang khusus bekerja di sub sektor kehutanan saja, pada umumnya lintas sub sektor dalam sektor pertanian. Untuk data industri kehutanan, masih bergabung dengan data ketenagakerjaan industri-industri lain.

Jumlah tenaga kerja dalam industri hasil pertanian sebanyak 5.815 tenaga kerja. (Badan Pusat Statistik, 2005)

\section{Peranan Sektor Kehutanan Dalam Produk Domestik Regional Bruto Kabupaten Gowa}

Sektor kehutanan termasuk salah satu sub sektor dalam sektor pertanian. Dalam sektor pertanian terdapat sub sektor lainnya yaitu sub sektor tanaman pangan, sub sektor perikanan, sub sektor perkebunan, dan sub sektor peternakan.

Adapaun kontribusi sub sektor kehutanan dalam perekonomian Kabupaten Gowa dapat dilihat pada Tabel 2. 
Table 2.Domestic products of bruto regional in Kabupaten Gowa at 2005

\begin{tabular}{|l|l|l|l|c|l|c|}
\hline No & \multirow{2}{*}{ Year } & \multicolumn{2}{|l|}{ PDRB Kab. Gowa } & \multicolumn{2}{|c|}{ PDBR Sektor Pertanian } & \multicolumn{2}{c|}{ PDRB Sub Sektor Kehutanan } \\
\cline { 3 - 7 } & & jml(juta Rp.) & jml (juta Rp.) & persentase & Jml (juta Rp.) & persentase \\
\hline 1. & 2000 & $1.070 .400,36$ & $551.256,2$ & 51,54 & $1.792,28$ & 0,17 \\
2. & 2001 & $1.243 .257,82$ & 640.277 .78 & 51,55 & $2.114,21$ & 0,17 \\
3. & 2002 & $1.410 .500,31$ & $740.512,66$ & 52,48 & $2.520,62$ & 0,18 \\
4. & 2003 & $1.592 .520,88$ & $848.813,63$ & 53,34 & $2.961,88$ & 0,19 \\
5. & 2004 & $1.830 .170,59$ & 963.767 .833 & 52,66 & $3.017,32$ & 0,16 \\
6 & 2005 & $2.123 .276,38$ & $1.107 .500,96$ & 52,16 & $3.315,99$ & 0,16 \\
& Rata-rata & $\mathbf{1 . 5 4 5 . 0 2 1 , 0 6}$ & $\mathbf{8 0 8 . 6 8 8 , 1 8}$ & $\mathbf{5 2 , 2 9}$ & $\mathbf{2 . 6 2 0 , 3 8}$ & $\mathbf{0 , 1 7}$ \\
\hline
\end{tabular}

Source: PDRB Kabupaten Gowa, 2005

Berdasarkan Tabel 2 terlihat bahwa kontribusi sektor pertanian dalam Produk Domestik Regional Bruto (PDRB) Kabupaten Gowa cukup tinggi, lebih dari setengah PDRB Kabupaten Gowa yaitu antara $51,54 \%$ sampai dengan $53,34 \%$ atau rata-rata $52,29 \%$. Namun kontribusi sub sektor kehutanan terhadap perekonomian Kabupaten Gowa sangat kecil hanya $0,16 \%$ sampai dengan $0,19 \%$ atau rata-rata $0,17 \%$. Hal ini disebabkan oleh karena penilaian sub sektor kehutanan hanya terbatas pada hasil hutan semata, terutama hasil hutan kayu dan hasil hutan non kayu seperti getah pinus.

Kontribusi sektor kehutanan dalam industri pertukangan dan insutri perkakas (meubel) tidak termuat secara eksplisit dalam perhitungan PDRB. Tetapi lebih diperhitungkan kearah sektor industri.

Produk domestik regional bruto atas dasar harga berlaku untuk sektor pertanian pada tahun 2004 sebesar Rp. 963.676,80 juta. Untuk sub sektor kehutanan hanya sekitar Rp. 3.017,32 juta, paling rendah dibandingkan sub sektor lainnya dalam sektor pertanian dimana yang tertinggi adalah sub sektor tanaman pangan (Kabupaten Gowa dalam Angka, 2006).

Ini berarti bahwa sektor pertanian hanya menyumbang 52,66 \% dari PDRB atas dasar harga berlaku tahun 2004 sebesar RP.1.830.170,60 juta. Dan sub sektor kehutanan hanya menyumbang $3,13 \%$ kepada sektor pertanian, dan $\quad 0,165 \%$ kepada PDRB Kabupaten Gowa (Kabupaten Gowa dalam Angka, 2006).

Indeks berantai produk domestik regional bruto atas dasar harga konstan 2000 untuk lapangan usaha pertanian pada tahun 2004 sebesar 102,64. dan untuk sub sektor kehutanan sebesar 91,40 , lebih rendah dari tanaman pangan, perkebunan, dan peternakan.

Indeks berantai produk domestik regional bruto atas dasar harga berlaku untuk lapangan usaha pertanian pada tahun 2004 sebesar 113,44. dan untuk sub sektor kehutanan sebesar 101,87, lebih rendah dari tanaman pangan, perkebunan, dan peternakan

\section{DAMPAK PEMUNGUTAN RENTE EKONOMI TERHADAP KELESTARIAN HUTAN DI KABUPATEN GOWA}

Nilai sumberdaya hutan dapat ternoda dengan adanya tiga faktor yang dapat menyebabkan penggundulan hutan, penyebab ini adalah:

1. Penebangan pohon untuk menghasilkan kayu gelondongan (baik legal maupun illegal logging)

2. Perladangan dan perambahan hutan

3. Kebakaran hutan

Penggundulan hutan merupakan dampak utama yang langsung dapat dilihat dari penebangan hutan secara meluas. Penggundulan hutan terjadi sebagai akibat ketidak-seimbangan antara laju kecepatan pengurangan areal hutan dengan jumlah pohon yang ditanam kembali plus kecepatan reproduksi alami dari tegakan (Ramli dan Ahmad, 1993).

Penebangan hutan terutama illegal logging telah memberikan kontribusi terbesar dalam penggundulan hutan akhir-akhir ini. Menurut Hidayati (2006), kerusakan hutan telah mencapai luasan sekitar 101,73 juta hektar di mana 59,62 juta hektar berada dalam kawasan hutan dan 42,11 juta hektar berada di laur kawasan hutan dengan laju deforestrasi mencapai 2,8 juta hektar pertahun. Sumber daya hutan Indonesia mengalami laju degradasi dan deforetrasi yang terus bertambah dengan analogi perhitungan, 
setiap satu menit hutan alam hilang seluas enam kali lapangan sepakbola.

Produksi kayu menimbulkan banyak ekternalitas, terdapat ekternalitas positif melalui dampak keterkaitan dengan ekonomi, produksi kayu juga membawa dampak negatif. Pengambilan kayu dari hutan alam telah menimbulkan eksternalitas ekonomi, lingkungan dan sosial (Ramli dam Ahmad, 1993)

Ekternalitas negatif terhadap lingkungan akan semakin memperburuk kelestarian hutan. Degradasi hutan yang semakin berkelanjutan akan semakin menurunkan potensi hutan, potensi kayu dan sekaligus akan berdampak negatif terhadap penarikan rente ekonomi hutan alam.

Rente ekonomi (economic rent) adalah balas jasa bagi faktor produksi di atas jumlah minimum yang diperlukan untuk menarik faktor tersebut ke dalam suatu kegiatan ekonomi tertentu. Dalam struktur pasar yang bersaing (competitive), balas jasa minimum yang diperlukan untuk menarik modal adalah tingkat keuntungan normal (Ahmad, 1992).

Dalam produksi kayu alam, ukuran yang relevan bagi rente ekonomi adalah stumpage value, yaitu nilai pasar dari pohon yang masih berdiri. Dalam sistem tender terbuka, maka stumpage value sama dengan nilai maksimum yang akan dibayar oleh seorang calon pemegang Hak Pengusahaan Hutan (HPH) atau pemegang izin pemanfaatan dan pemungutan hasil hutan kayu untuk memperoleh hak menebang pohon di suatu wilayah yang telah ditetapkan. Dalam sistem tender yang lain, stumpage value dari hutan alam adalah selisih antara harga kayu alam dipasar internasional dengan seluruh biaya faktor produksi yang dikeluarkan dalam memproduksi dan mengangkut ke pelabuhan ekspor. Rente ekonomi dari sumberdaya alam terbentuk karena kelangkaan dan pelbagai keuntungan lokasi dan biaya berbanding (comparative cost) lainnya yang di dalam dirinya (inherent) dimiliki oleh cadangan komoditi tertentu.

Terdapat beberapa jenis penarikan rente ekonomi dari hutan di Indonesia, diantaranya adalah luran Hasil Hutan $(\mathrm{IHH})$ atau provisi sumberdaya hutan, dana reboisasai dan luran IUPHHK (luran Izin Usaha Pemanfaatan Hasil Hutan Kayu).

Bila melihat kontribusi sub sektor kehutanan terhadap PDRB Kabupaten Gowa sangat sedikit hanya sekitar $0,16 \%$. Kontribusi sub sektor kehutanan hanya dinilai berdasarkan manfaat langsung yang diberikan hutan melalui hasil hutan kayu dan hasil hutan non kayu. Sementara manfaat tidak langsung, penilaiannya bahkan dikategorikan pas sub sektor atau sektor lain, sehingga tidak tercermin sebagai manfaat dari keberadaan hutan.

Dibandingkan dengan luas hutan yang rusak mencapai 35.449,62 ha, yaitu sekitar 56,18 $\%$ dari luas hutan Kabupaten Gowa. Dapat dipastikan begitu besar beban yang ditanggung oleh hutan dalam menopang perekonomian masyarakat seperti peladang, perambah hutan, dan lain-lain.

Dalam rangka menjaga kelestarian hutan, telah dilakukan kegiatan rehabilitasi hutan dan lahan melalui Gerakan Nasional Rehabilitasi Hutan dan Lahan (GNRHL). Kegiatan GNRHL pada tahun 2005 direncanakan seluas 1350 ha dengan biaya sebesar Rp. 5.273.006.000,namun yang terealisasi seluas $1.042,50$ ha dengan dana sebesar Rp. 3.552.120.000,- . Sampai pada tahun 2005 luas lahan yang telah direhabilitasi baik di dalam kawasan hutan maupun di luar kawasan hutan seluas 2400 ha yang terdiri dari 1850 ha untuk reboisasi, 450 ha untuk hutan rakyat dan 100 ha untuk tanaman lainnya (Dinas Kehutanan, 2005).

Luas hutan rakyat seluruhnya di Kabupaten Gowa sampai dengan tahun 2005 adalah 2577 ha yang terdiri dari hutan rakyat dengan fungsi lindung 2421 ha, hutan rakyat dengan fungsi budidaya seluas 150 ha. Hutan rakyat ini ditanam pada 5 kecamatan yaitu Kecamatan Parangloe, Tinggi Moncong, Tompobulu, Bungaya dan Bontomarannu (Dinas Kehutanan, 2005).

Kegiatan rehabilitasi hutan dan lahan di Kabupaten Gowa pada tahun 2007 direncanakan seluas $1400 \mathrm{Ha}$ berdasarkan Dinas Kehutanan Kabupaten Gowa. Kegiatan ini dilaksanakan pada tujuh kecamatan, yaitu :

1. Kecamatan Tombolopao seluas 350 ha

2. Kecamatan Tinggi Moncong, seluas 50 ha

3. Kecamatan Parigi 100 ha

4. Kecamatan Bungaya, seluas 250 ha

5. Kecamatan Tompo Bulu seluas 200 ha

6. Kecamatan Biringbulu seluas 100 ha

7. Kecamatan Bonto Lempangan seluas 350 ha.

Pemanfaatan rente ekonomi untuk kegiatan rehabilitasi lahan pada tahun 2005 telah dimanfaatkan sebesar Rp. 142.384.858,- untuk kegiatan rehabilitasi seluas $95,50 \mathrm{Ha}$. Dana ini berasal dari DAK-DR $40 \%$ (dana alokasi khusus- 
dana reboisasai $40 \%$ ) yang merupakan bagian yang dikelola oleh daerah penghasil.

Bila melihat luasnya hutan yang rusak dengan kemampuan pendanaan pertahun pada tingkat kabupaten, masih tidak seimbang. Oleh karena itu kegiatan GNRHL dengan durasi 5 tahun sangat membantu kegiatan rehabilitasi ini.

\section{PENUTUP}

Bila dianalisis secara menyeluruh, peranan hutan dalam perekonomian Kabuaten Gowa sangat besar, dengan memasukkan manfaat langsung maupun manfaat tidak langsung yang dapat disumbangkan oleh keberadaan hutan. Manfaat ini adalah berasal dari produksi hasil hutan kayu dan hasil hutan non kayu, fungsi rekreasi, dan fungsi lindung.

Rente ekonomi mempunyai peranan dalam menjaga kelestarian hutan melalui kegiatan rehabilitasi lahan, baik kegiatan GNRHL yang didanai oleh pemerintah pusat maupun pemanfaatan DAK-DR $40 \%$ yang merupakan bagian wilayah penghasil.

\section{DAFTAR PUSTAKA}

Ahmad, M. 1992. Rente ekonomi dalam Eksploitasi Hutan Tropis. Majalah Prisma edisis 6 tahun XXI. PT. Pustaka LP3ES Indonesia. Jakarta.
Badan Pusat Statistik, 2005. Produk Domestik Regional Bruto. Badan Pusat Statistik Kabupaten Gowa Sulawesi Selatan.

Badan Pusat Statistik. 2006. Kabupaten Gowa dalam Angka 2006. Badan Pusat Statistik Kabupaten Gowa Sulawesi Selatan.

Departemen Kehutanan Republik Indonesia. 2006. Undang-Undang Kehutanan Nomor 41 tahun 1999. cetakan 1. Pustaka Pelajar. Jakarta.

Hidayati, R., C. Tambunan, A. Nugraha, dan I. Aminuddin. 2006. Pemberantasan Illegal Logging dan Penyelundupan Kayu. Wana Aksara Banten.

Ramli, R. dan M. Ahmad. 1993. Rente Ekonomi Pengusahaan Hutan Indonesia. Wahana Lingkungan Hidup Indonesia . Jakarta

Soeparmoko, M. 2002. Buku Pedoman Penilaian Ekonomi Sumberdaya Alam dan Lingkungan (Konsep dan Metode Perhitungannya). Edisi pertama. BPFE. Yogyakarta.

Soeparmoko, M. 1994. Ekonomi Sumberdaya Alam Dan Lingkungan (Suatu Pendekatan Teoritis) Edisi kedua. BPFE. Yogyakarta.

Wirakusumah, S. 2003. Mendambakan Kelestarian Sumber Daya Hutan Bagi Sebesar-Besarnya Kemakmuran Rakyat Suatu Telaah Ekonomi. Penerbit Universitas Indonesia. Jakarta.

Diterima : 29 Mei 2007

\section{Syamsu Alam}

Lab. Kebijakan dan Kewirausahaan Kehutanan

Fakultas Kehutanan, Universitas Hasanuddin

Kampus Tamalanrea, Jl. Perintis Kemerdekaan Km. 10, Makassar 90245

Telp./Fax. 0411-585917. Indonesia

\section{Hajawa}

Fakultas Kehutanan, Universitas Satria Makassar

Kampus Veteran Selatan, Makassar. Indonesia 